\title{
ALAT PERTANIAN TRADISIONAL \\ SEBAGAI WARISAN KEKAYAAN BUDAYA BANGSA \\ (Traditional of Agricultural Equipment as Nation Cultural Heritage Property)
}

\author{
Lilyk Eka Suranny \\ Kantor Penelitian, Pengembangan, Ilmu Pengetahuan dan Teknologi Kabupaten Wonogiri \\ lilik_fd@yahoo.com
}

\begin{abstract}
Traditional farm equipment is one of the cultural richness of Indonesia. Modernization in agriculture causes decreasing of traditional farm equipment using by farmers. There are many different kinds of traditional farm equipment made by our ancestors in earlier time, for example plows, harrows, hoes, ani-ani, sickle, etc. In some region of Indonesia, the traditional farm equipments has different local name although has the same usability. This traditional farm equipment contains adi luhung values according to the personality of the Indonesian nation. Therefore, traditional farm equipment needs to be preserved from exitinction and can be inherited to the next generations.
\end{abstract}

Keywords: traditional farm equipment, cultural heritage, local genius

\begin{abstract}
ABSTRAK
Alat pertanian telah dibuat oleh manusia prasejarah sejak masa neolitik. Alat pertanian tradisional merupakan salah satu kekayaan budaya bangsa Indonesia. Modernisasi di bidang pertanian menyebabkan berkurangnya penggunaan alat pertanian tradisional oleh petani. Tulisan ini akan menjelaskan mengenai berbagai peralatan pertanian tradisional yang digunakan untuk bercocok tanam baik dari fungsi maupun cara pemakaiannya. Selain itu penulis mencoba untuk mengupas nilai-nilai yang terkandung dalam penggunaan peralatan tradisional tersebut. Metode yang digunakan dalam tulisan ini yaitu observasi, wawancara dan studi pustaka. Peralatan pertanian tradisional merupakan bentuk kearifan lokal, memiliki nilai tradisi dan budaya yang telah diwariskan oleh nenek moyang.
\end{abstract}

Kata kunci: alat pertanian tradisional, kekayaan budaya, kearifan lokal

Tanggal masuk : 22 April 2014

Tanggal diterima : 2 Juni 2014 


\section{PENDAHULUAN}

Indonesia sekarang dikenal sebagai negara agraris yang sebagian besar penduduknya bermata pencaharaian sebagai petani. Sebelum mencapai taraf pertanian, awalnya sejarah manusia untuk mempertahankan hidup dilakukan dengan mengumpulkan hasil bumi dan berburu hewan di sekitar lingkungan. Kegiatan tersebut dikenal dengan sebutan "berburu dan meramu". Seiring dengan perkembangan zaman, kegiatan berburu dan meramu berganti dengan bercocok tanam. Berdasarkan data arkeologis kegiatan bercocok tanam dilakukan oleh masyarakat pada zaman dulu secara sederhana dengan membuka hutan untuk dijadikan lahan pertanian dan menanam berbagai jenis umbi-umbian. Setelah musim panen, lahan pertanian yang lama ditinggalkan kemudian mencari lahan yang baru dengan merambah hutan. Mereka menganggap tanah yang lama sudah tidak dapat dipakai lagi untuk menanam dalam waktu yang cepat (Soejono dalam Hartati, 2011). Semakin lama lahan pertanian semakin terbatas, sehingga mereka mengubah sistem pertanian yang berpindah-pindah dengan membuka hutan, beralih ke sistem pertanian yang permanen dengan menerapkan sistem pengolahan tanah untuk ditanami padi. Mulai saat inilah pertanian padi dikenal masyarakat (Widyantoro dalam Hartati, 2011).

Berbagai bukti sejarah yang menggambarkan sistem pertanian masa lalu yakni ditemukannya berberapa prasasti dan temuan peninggalan alat-alat pertanian. Prasasti Tugu yang dikeluarkan oleh Raja Purnawarman berisi penggalian sungai untuk saluran yang disebut Gomati, sepanjang $12 \mathrm{~km}$ selama 21 hari yang kemungkinan digunakan untuk irigasi atau bendungan dan pelayaran sungai (Wuryantoro dalam
Hartati, 2011). Pada masa Kerajaan Majapahit pertanian mendapat perhatian yang besar dari raja dan penguasa. Raja memberi perlindungan berupa penetapan tanah pertanian (Pigeaut dalam Hartati, 2011). Temuan alat-alat pertanian seperti mata bajak, kapak perimbas, dll membuktikan bahwa sudah sejak lama sistem pertanian dikenal oleh masyarakat.

Sistem pertanian tradisional yang diterapkan masyarakat pada jaman dulu dilakukan secara gotong royong. Sistem pertanian tradisional yang menggunakan konsep gotongroyong dalam penggarapan lahan pertanian digambarkan oleh Emile Durkheim sebagai ciri masyarakat tradisional. Dalam pandangan Durkheim masyarakat tradisional biasanya tinggal di daerah pedesaan dengan pembagaian kerja yang relatif lebih rendah. Dengan pembagian kerja terbatas, masyarakat tradisional membangun sistem solidaritas mekanis yang muncul berdasarkan atas kesamaan profesi mereka (Djhonson, 1994: 183). Selain untuk memenuhi kebutuhan sehari-hari, hasil pertanian juga dijual. Sebelum mengenal sistem uang, masyarakat jaman dulu menukar hasil pertanian dengan barang kepada orang lain dengan cara barter. Cara barter mulai ditinggalkan sejak masyarakat mulai mengenal uang.

Masyarakat tradisional mengenal dua pola pertanian, yakni pertanian lahan kering (ladang/tegal) dan lahan basah (sawah). Untuk pertanian kering biasanya ditanami umbi-umbian, kacang-kacangan, buah-buahan, dan sayuran. Sedangkan untuk pertanian basah biasanya ditanami padi. Ada dua jenis alat pertanian yang digunakan, yakni alat pertanian tradisional dan modern. Alat pertanian tradisional bentuknya sederhana dan digerakkan menggunakan tenaga manusia, sedangkan alat pertanian modern digerakkan dengan menggunakan 
mesin. Alat pertanian telah dibuat oleh manusia sejak jaman becocok tanam, dimana manusia prasejarah telah mengenal pertanian. Pada jaman batu alat pertanian dibuat dengan menggunakan batu dan pada jaman logam alat pertanian dibuat menggunakan logam (perunggu dan besi). Dampak positif dari penggunaan alat pertanian tradisional yakni ramah lingkungan, karena tidak ada kerusakan alam ataupun pencemaran yang ditimbulkan sehingga pelestarian alam terus berjalan.

Perkembangan

iptek menyebabkan modernisasi pertanian yang mendorong penggunaan peralatan modern dengan teknologi canggih. Penggunaan peralatan modern dimaksudkan untuk meningkatkan produktivitas hasil pertanian karena dianggap lebih efektif dan efisien. Alat pertanian tradisional semakin ditinggalkan oleh petani. Penggunaan peralatan modern ini ternyata juga membawa efek negative, diantaranya kurang ramah lingkungan. Oleh karena itu, peralatan pertanian tradisional ini perlu dilestarikan untuk mengurangi dampak negatif dari penggunaan peralatan modern sekaligus dapat melestarikan kearifan lokal, nilai tradisi dan budaya. Justru itu, pengetahuan mengenai peralatan pertanian tradisional diperlukan sebagai sarana menjaga kelestarian

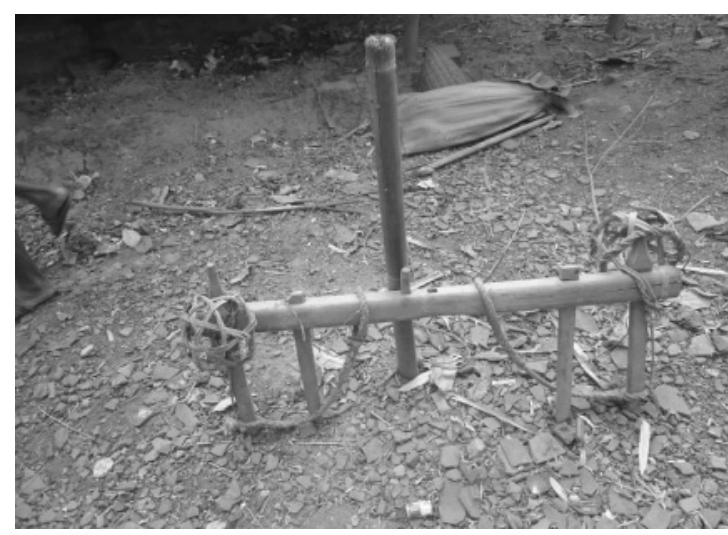

Gambar. 1 Bajak tradisional (dokumentasi Lilyk) kekayaan budaya bangsa. Dalam tulisan ini akan dijelaskan mengenai berbagai peralatan pertanian tradisional yang digunakan untuk bercocok tanam, baik dari fungsi maupun cara pemakaiannya. Selain itu penulis mencoba untuk mengupas nilai-nilai yang terkandung dalam penggunaan peralatan tradisional tersebut.

\section{ALAT PERTANIAN TRADISIONAL DAN FUNGSINYA}

\section{Bajak (Luku/Waluku)}

Bajak merupakan alat pertanian yang digunakan untuk mengolah tanah sebelum ditanami. Bajak digunakan pada pengolahan tanah pertama (primary tillage equipment) sebelum proses selanjutnya yang diperlukan. Di pulau Jawa, bajak dikenal dengan nama luku/waluku, suku bangsa Batak menyebutnya dengan tenggala (bahasa Karo), dan suku Minahasa menyebut dengan nama pajeko. sementara Orang Aceh menyebutnya langa.

Bajak orang Jawa memiliki beberapa bagian, yaitu cekelan, pancadan, tandhing, singkal, dan pasangan. Cekelan adalah bagian dari bajak yang dipegang oleh orang yang mengolah lahan. Cekelan harus dipegang kuat agar bajak tidak mudah lepas. Pancadan adalah pijakan kaki dari pembajak. Pada saat membajak, kaki harus berpijak salah satu bagian dari alat dengan tekanan kuat agar bajak dapat terbenam ke tanah dan dapat membalik tanah saat ditarik. Tandhing atau pasak digunakan untuk menguatkan sambungan agar bajak tidak goyang. Singkal merupakan bagian dari bajak yang digunakan untuk membalik tanah. 


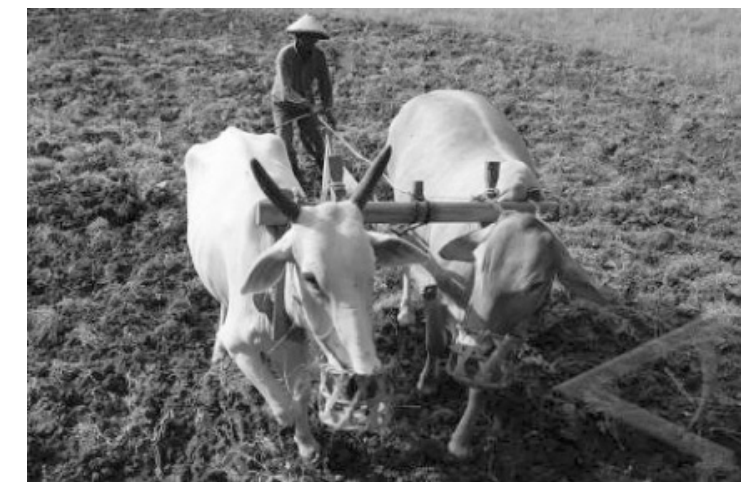

Gambar 2. Petani sedang membajak sawah (dokumentasi Lilyk)

Mata bajak (kejen) terbuat dari besi atau baja berbentuk runcing untuk menembus tanah yang akan dibajak. Mata bajak ini terdiri dari baji tiga sisi dengan tamping dan bidang datar sisi pemotong kejen sebagai sisi datarnya, sedangkan bagian atas kejen dan singkal sebagai sisi lengkungnya. Pasangan berada di leher hewan penarik bajak yang berfungsi sebagai pengendali. Untuk menarik bajak, petani menggunakan bantuan hewan yang jinak, seperti kerbau atau sapi. Jumlahnya juga bermacam-macam sesuai kebutuhan, bisa seekor sapi/ kerbau ataupun dua ekor sapi/kerbau. Sapi yang digunakan saat membajak bagian mulutnya ditutup menggunakan brongkos. Tujuannya agar sapi tidak makan saat digunakan untukmembantu menarik bajak. Karena apabila tidak diberi penutup mulut, sapi atau kerbau cenderung lambat kerjanya. Sebelum digunakan, sapi terlebih dahulu diberi makan dan minum sampai kenyang, sehingga cukup tenaganya untuk membajak.

\section{Garu}

Garu adalah peralatan pertanian yang digunakan untuk pengolahan tanah tahap kedua (secondary tillage equipment) setelah pengolahan tanah menggunakan bajak. Pada saat dibajak tanah masih berupa bongkahanbongkahan besar yang harus diratakan agar dapat ditanami. Selain

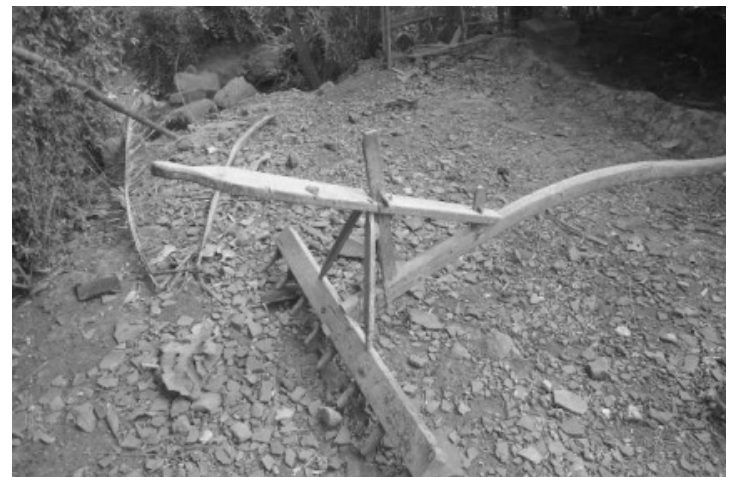

Gambar 3. Garu (dokumentasi Lilyk)

meratakan, garu juga berfungsi untuk meningkatakan unsur hara tanah. Garu digunakan untuk menghancurkan sisasisa tanaman dan mencampurkannya ke dalam tanah.

Garu terdiri atas pegangan dan mata. Pegangan garu terbuat dari kayu yang digunakan untuk mengarahkan garu pada saat mengolah tanah sedangkan mata garu ada yang terbuat dari kayu ataupun besi. Cara penggunaanya yaitu gagang garu dipegang dengan erat menggunakan kedua tangan, kemudian mata garu diarahkan pada tanah yang akan diratakan. Susunan mata garu yang ditarik kedepan menyebabkan bongkahan- bongkahan tanah yang telah dibajak menjadi lebih rata.

\section{Cangkul}

Cangkul merupakan salah satu alat tradisional yang digunakan dalam pertanian. Cangkul digunakan untuk berbagai pekerjaan, antara lain: (1) membelah, membalik, dan menggemburkan tanah; (2) mengerjakan tanah pada petakpetak sempit dan sudut-sudut yang tidak dapat dikerjakan menggunakan bajak; (3) mengolah tanah berbatu dan menyisir tanggul; (4) membuat parit; (5) menggali lubang pada saat menanam kacang tanah, jagung, dan tanaman lainnya.

Cangkul memiliki dua bagian yaitu mata cangkul (pacul) yang terbuat 


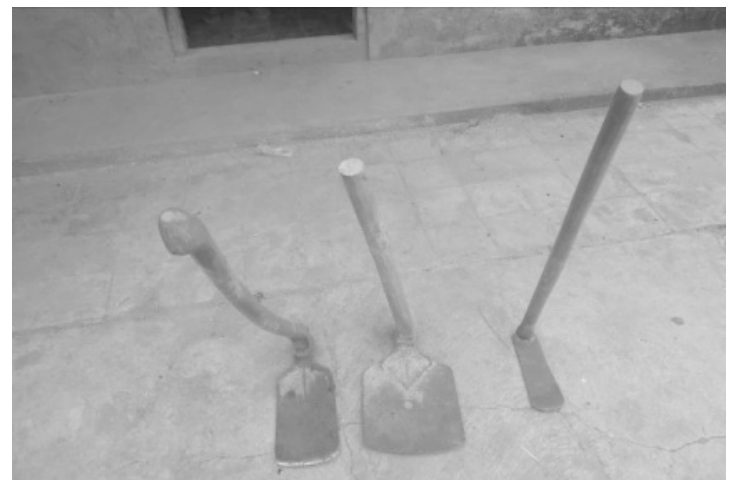

Gambar 4. Macam-macam bentuk cangkul (dokumentasi Lilyk)

dari besi, berbentuk persegi atau bulat dan doran (pegangan) yang terbuat dari kayu sebagai pegangan. Cara penggunaanya: pegang doran dengan kedua tangan, kemudian arahkan pada tanah yang akan diolah sesuai kebutuhan. Pada saat mencangkul tanah, pastikan posisi badan membungkuk turun kebawah untuk memudahkan proses pencangkulan.

\section{Ani-ani (ketam)}

Ani-ani adalah alat untuk memotong tangkai tanaman padi pada saat panen. Ani-ani terdiri atas 2 bagian utama, yaitu pisau yang terbuat dari besi beserta papan yang digunakan untuk meletakkan pisau dari kayu. Tangkai ani-ani yang terbuat dari bambu atau kayu. Alatnya sangat sederhana dan mudah penggunaannya. Cara menggunakan ani-ani, yaitu tangan kanan memegang papan pegangan dengan erat, sementara tangan kiri memegang tanaman padi yang akan dipotong, kemudian arahkan pisau pada tanaman padi yang akan dipotong.

Keuntungan menggunakan aniani pada saat memanen padi adalah petani dapat memilah padi yang sudah siap panen dan yang belum matang Namun demikian, alat ini kurang efektif karena memerlukan banyak waktu dan tenaga kerja untuk memanen padi. Oleh karena itu, ani-ani semakin ditinggalkan petani dan beralih ke alat pertanian modern, yakni menggunakan teknologi moderen untuk memanen, misalnya mesin mower atau reaper yang dapat merobohkan tangkai padi dalam waktu yang cepat.

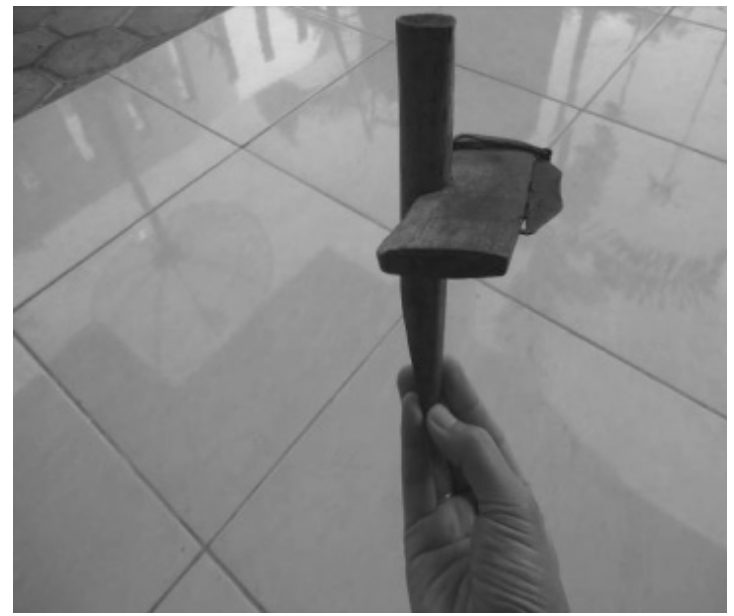

Gambar 5. Ani-ani (ketam) (dokumentasi Lilyk)

\section{Cangkul kecil (Kering)}

Cangkul kecil yang orang Jawa sebut kering merupakan salah satu alat pertanian yang mulai ditinggalkan petani sekarang. Alat ini berfungsi untuk membersihkan rumput atau tanaman pengganggu di ladang atau tegalan. Kering sangat efektif digunakan saat membersihkan rumput di sela-sela tanaman utama yang jaraknya dekat yang jika menggunakan cangkul akan sangat kesulitan bahkan justru bisa mengenai tanaman utama sehingga akan mati. Alat ini terdiri dari dua bagian utama, yaitu besi tipis mirip cangkul dengan ukuran yang lebih kecil dan

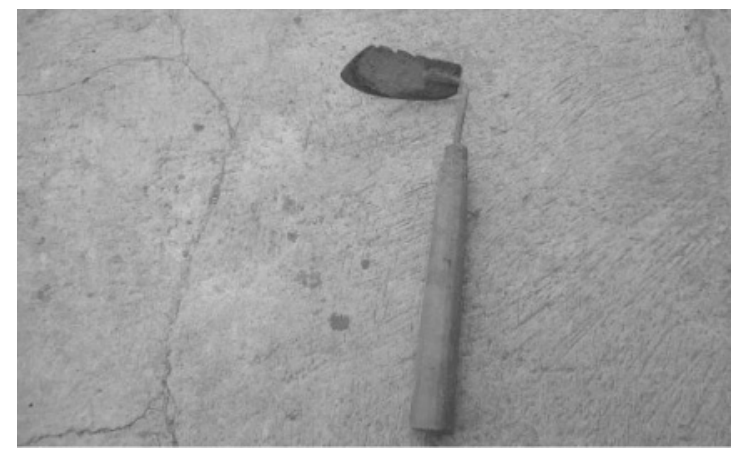

Gambar 6. Cangkul kecil (kering) (dokumentasi Lilyk) 
tangkai yang terbuat dari kayu sebagai pegangan. Cara menggunakan alat ini: pegang tangkai atau gagang kering, kemudian arahkan kering ke arah rumput yang akan dibersihkan. Pada saat menggunakan kering hendaknya dilakukan dengan posisi jongkok untuk mempermudah pekerjaan yang dilakukan. Dengan perkembangan teknologi alat ini semakin ditinggalkan petani dan beralih ke mesin pemotong rumput untuk membersihkan tanaman pengganggu ataupun obat kimia yang disemprotkan ke rumput.

\section{Tongkat Tunggal (Taju)}

Tongkat tunggal merupakan salah satu alat pertanian tradisional yang berfungsi untuk membuat lubang pada saat menanam. Tongkat tunggal ini oleh suku Nias disebut toru, dan dalam bahasa Karo disebut engkol, sedangkan orang Jawa menyebutnya taju. Alat ini biasanya digunakan untuk menanam jagung, kacang tanah, kacang hijau, ataupun kedelai di ladang.

Bentuk taju sangat sederhana, hanya berupa tongkat lurus yang salah satu bagian di ujungnya dibuat lancip. Tonggat tunggal terbuat dari kayu secara keseluruhan ataupun ada juga yang membuat bagian lancip dengan dilapisi besi agar lebih tajam pada saat digunakan. Cara menggunakan taju juga sangat mudah, yakni tongkat tunggal dipegang dengan posisi ujung yang lancip berada di bawah. Setelah itu, tancapkan tongkat tunggal ke dalam tanah dan segera angkat setelah menghujam tanah. Hasilnya, akan terbentuk lubang dan siap untuk ditanami benih jagung ataupun tanaman pertanian lainnya. Alat ini semakin ditinggalkan oleh petani dan beralih memanfaatkan alat penanam modern (seeder), yakni menggunakan tenaga mesin. Bahkan seeder sudah memiliki kegunaan multifungsi, yaitu menanam sekaligus memupuknya.

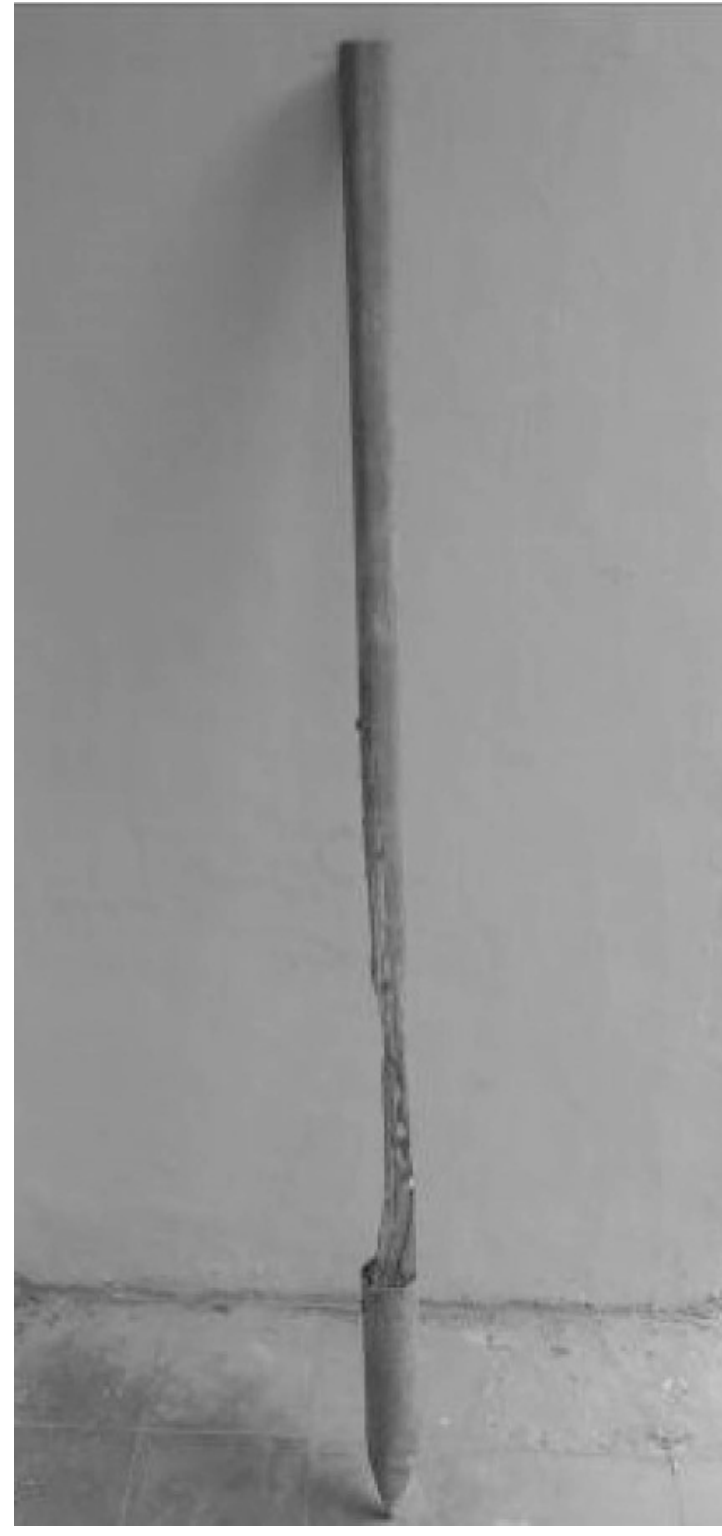

Gambar 7. Tongkat tunggal (dokumentasi Lilyk)

\section{Sabit (Arit)}

Sabit adalah alat pertanian yang berbentuk pisau melengkung untuk memotong tanaman, rumput, bahkan kayu. Sabit dalam bahasa Jawa dikenal dengan nama arit, orang Batak menyebut sabi-sabi. Sabit terdiri dari dua bagian utama, yaitu lengkungan tajam terbuat dari besi yang berfungsi sebagai pemotong dan pegangan sabit terbuat dari kayu. Cara menggunakan sabit adalah gagang/pegangan sabit dipegang menggunakan tangan kanan dengan erat agar tidak lepas, 


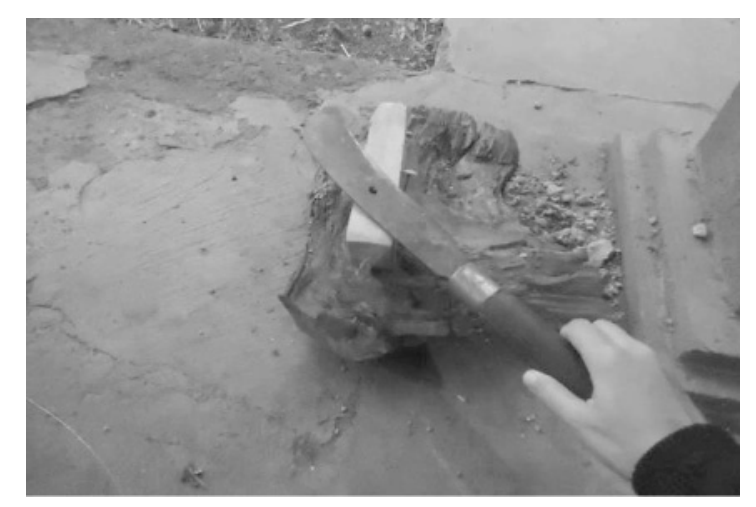

Gambar 8. Batu asah (dokumentasi Lilyk)

sementara tangan kiri memegang tanaman/rumput yang akan dipotong. Selanjutnya, ayunkan sabit ke arah tanaman yang hendak dipotong.

\section{Parang (Arit Bendo)}

Parang digunakan untuk memotong batang tanaman atau kayu yang lebih keras dan besar. Parang atau Arit bendo menggunakan pisau besi yang lebih tebal daripada bentuk arit yang lain agar tidak patah pada saat digunakan.

\section{Arit Babatan}

Arit babatan digunakan untuk memotong rumput ataupun tanaman pertanian seperti padi, kacang tanah, jagung, ataupun semak-semak. Bentuk pisaunya lebih tipis untuk mempermudah dalam pemakaiannya.

Semakin lama ketajaman dari sabit akan berkurang apalagi jika jarang dipakai. Untuk meningkatkan

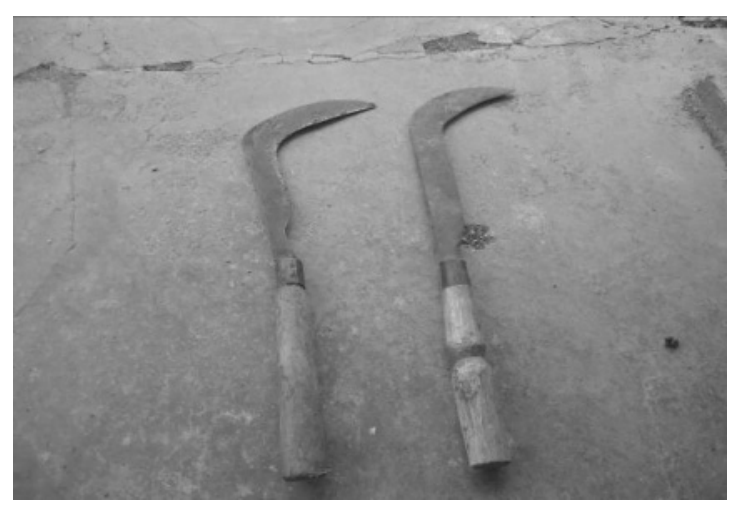

Gambar 9 Arit babatan (dokumentasi Lilyk) ketajaman sabit ini, petani jaman dulu mengasahnya dengan menggunakan batu. Orang jawa sering menyebut batu asah dengan nama ungkal. Caranya menggunakannya yaitu bagian sabit yang akan ditajamkan digosok-gosokkan pada batu asah searah secara berulang-ulang sampai sabit yang di asah tersebut tajam.

\section{Alat Perontok (Gerejag/gebotan)}

Gerejag/gebotan merupakan alat pertanian yang dipakai pada saat panen padi. Alat ini digunakan untuk merontokkan padi dari tangkainya. Gerejag terbuat dari bambu dan kayu yang disusun membentuk segitiga. Cara menggunakannya: padi yang telah dipanen diayunkan ke alat tersebut beberapa kali, sehingga bulir padi bisa lepas dari tangkainya. Alat ini sangat sederhana dan sepenuhnya menggunakan tenaga manusia. Penggunaanya semakin ditinggalkan petani karena kurang efektif dan kemudian mereka beralih ke mesin perontok padi (thresher) yang dinilai lebih mengguntungkan.

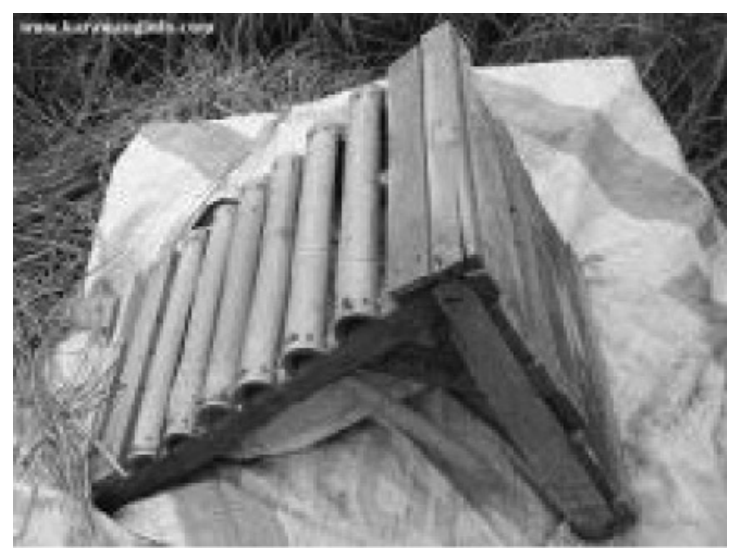

Gambar 10. Gerejag/gebotan

(sumber:http://kelompokternakpucakmanik. blogspot.com)

\section{Keranjang (Tenggok atau Dunak)}

Keranjang merupakan alat tradisional yang digunakan untuk mengangkut hasil panen petani. Keranjang terbuat dari anyaman 
bambu. Orang Jawa menyebut keranjang dengan nama tenggok atau dunak, sedangkan orang Nias menyebutnya dengan ndraga (anonim, 2011). Beberapa daerah di Jawa ada juga yang memakai dua buah keranjang (dunak) dan diangkat menggunakan pikulan. Pikulan dibuat dari bambu sehingga pada saat mengagkat dunak, pikulan tersebut akan lentur mengikuti ayunan langkah petani yang membawa. Agar dapat dibawa, dunak ini dikaitkan pada tali yang diikat dengan pikulan. Keberadaan serangkaian alat angkut

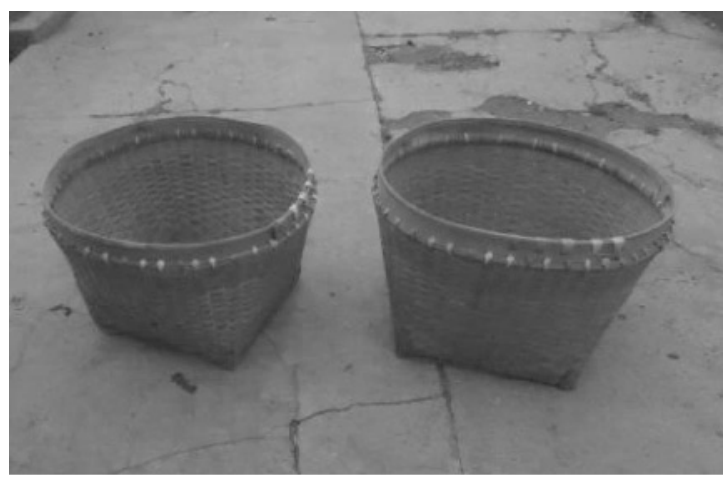

Gambar 11. Keranjang (tenggok) (dokumentasi Lilyk)

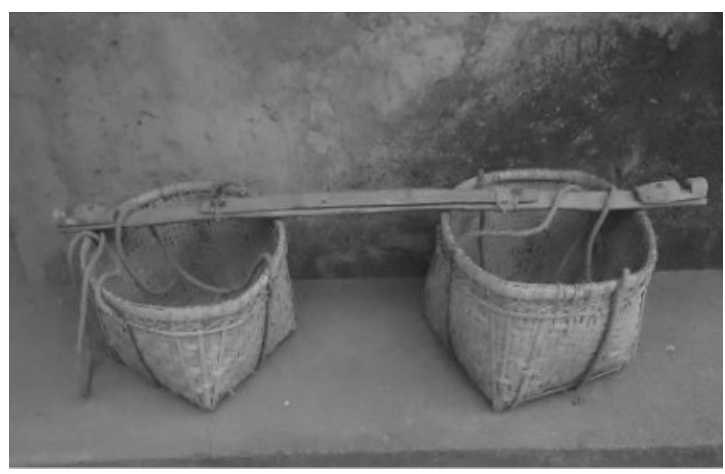

Gambar 12. Dunak (dokumentasi Lilyk)

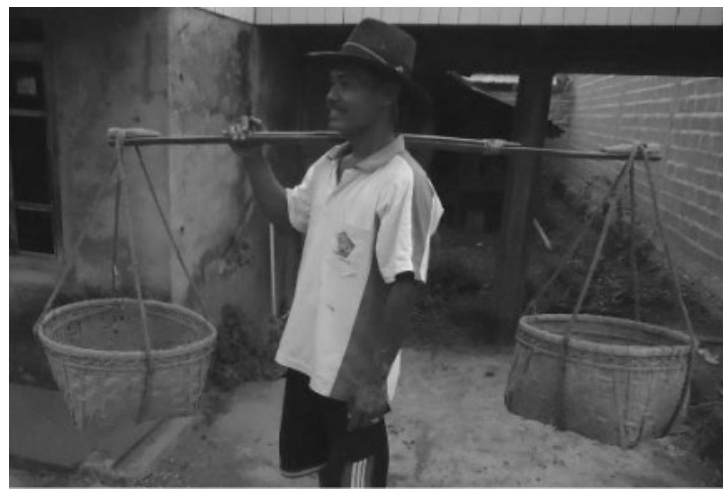

Gambar 13. Pikulan (dokumentasi Lilyk) tradisional ini semakin langka karena petani memilih menggunakan trealer, mobil, sepeda motor, hand traktor rakitan yang dilengkapi tempat angkut hasil pertanian, dan lain-lain.

\section{Lesung, Lumpang, Alu, Tampi (Nyiru)}

Lesung, lumpang, alu, dan tampi merupakan serangkaian alat yang digunakan pada saat pasca panen padi. Lesung adalah wadah atau tempat menumbuk padi untuk memisahkan padi dari kulitnya, berbentuk seperti perahu panjang, terbuat dari kayu yang keras atau batu. Selain itu, lesung juga sering dipakai untuk menumbuk beras yang akan dibuat tepung ataupun untuk menumbuk rempah-rempah. Orang Nias menyebutnya sebagai losu (Anonim 2011). Lumpang juga merupakan alat yang digunakan untuk menumbuk padi ataupun beras, terbuat dari kayu ataupun batu dan biasanya juga terdapat di ujung-ujung lesung. Alu adalah alat yang digunakan untuk menumbuk padi agar lepas dari sekamnya, berfungsi sebagai alat pendamping lesung. Alu berbentuk seperti tongkat kayu yang pada bagian tengah dibuat agak kecil, berfungsi sebagai pegangan tangan penumbuk padi. Pada bagian bawah alu agak besar dan tumpul yang digunakan untuk menumbuk padi.

Tampi (nyiru) adalah alat tradisional yang terbuat dari anyaman

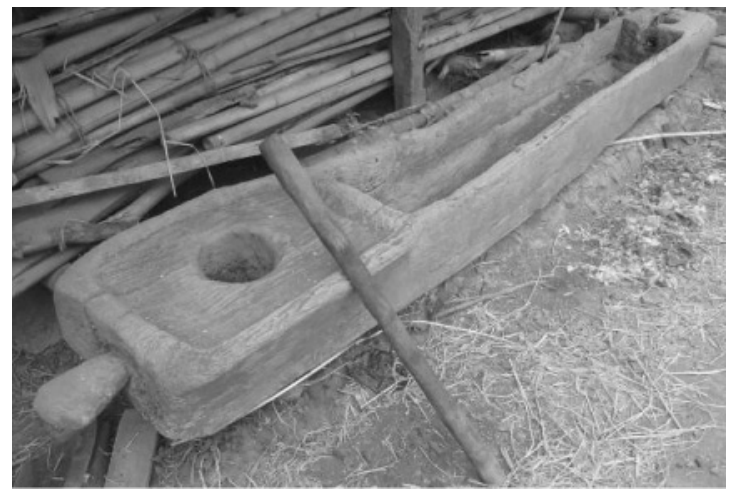

Gambar 14. Lesung (dokumentasi Lilyk) 


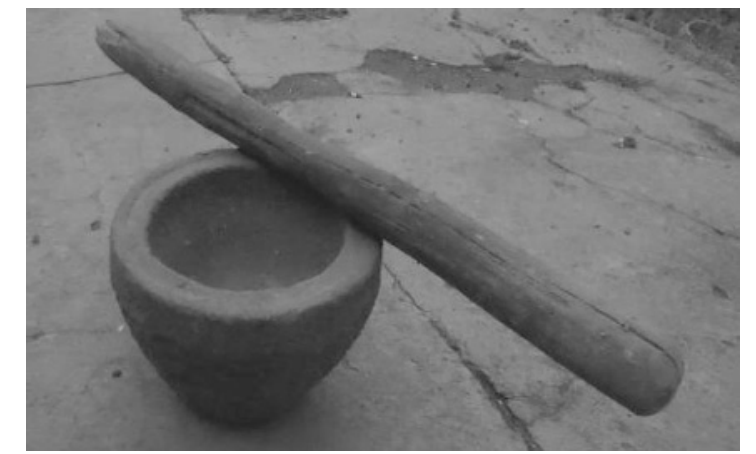

Gambar 15. Lumpang dan Alu (dokumentasi Lilyk)

bambu dan bentuknya bundar, biasa digunakan untuk memisahkan padi yang telah ditumbuk dari kulitnya. Orang jawa menyebut tampi dengan sebutan tampah, sedangkan Orang Nias menyebutnya dengan niru. Cara menggunakan tampi, yaitu dengan memasukkan padi yang telah ditumbuk ke dalam tampi dan diayunkan serta diputar-putar (Orang Jawa menyebutnya di interi). Sebelum ditumbuk, padi dikeringkan terlebih dahulu dengan dijemur dibawah sinar matahari agar mudah untuk melepaskan kulitnya. Kulit padi ini biasanya disebut merang (sekam), dulu sering digunakan sebagai bahan bakar untuk memasak. Di Jawa, kegiatan menumbuk padi biasanya dilakukan oleh ibu-ibu petani secara gotong-royong. Serangkaian alat diatas semakin ditinggalkan petani dan beralih ke mesin penggilingan yang lebih modern. Bahkan untuk mengeringkan hasil panen, petani sudah menggunakan alat modern dengan mesin pengering (dryer).

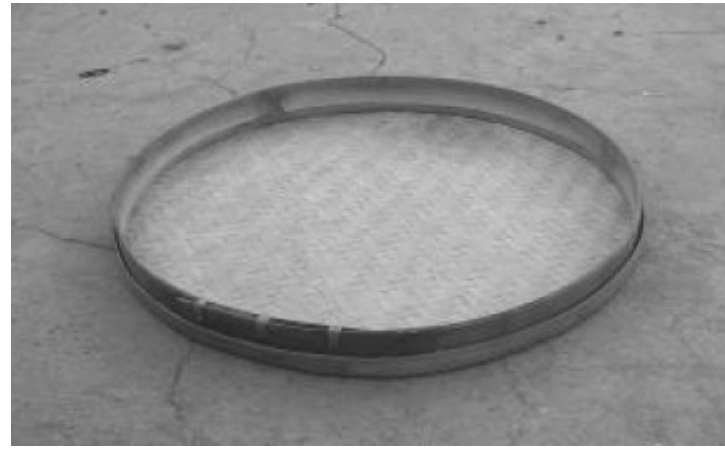

Gambar 16. Tampi (Nyiru) (dokumentasi Lilyk)

\section{NILAI-NILAI ALAT TRADISIONAL}

\section{Nilai ekonomis}

Nilai ekonomis tercermin dari bahan baku yang digunakan untuk membuat peralatan pertanian tradisional, yakni biaya yang relatif murah. Bahan-bahan yang dipakai dapat diperoleh secara mudah di alam, antara lain kayu, bambu, batu, dan lainlain. Proses pembuatan dan alat yang digunakan untuk membuat tergolong sederhana. Pembuatan alat pertanian tradisional biasanya dilakukan sendiri oleh petani, misalnya untuk pembuatan bagian-bagian bajak, mereka mencari bahan kayu yang keras. Untuk mata bajak yang terbuat dari besi, petani biasanya meminta bantuan pandai besi untuk membuatkannya. Contoh lain, dalam membuat keranjang, petani biasanya mencari bambu di lingkungan sekitar kemudian membuat anyaman sehingga menghasilkan barang sesuai keinginan mereka. Petani pada jaman dulu dikenal sangat kreatif dalam membuat peralatan pertanian dengan memanfaatkan bahan-bahan berasal dari alam sekitarnya.

\section{Nilai budaya}

Beberapa nilai budaya yang tercermin dalam penggunaan peralatan pertanian tradisional dapat dilihat pada beberapa kegiatan. Misalnya pada saat membajak sawah dilakukan sambil menyanyikan senandung sebagai penyemangat kerja yang berisi wejangan/petuah untuk generasi muda. Bunyi-bunyian lesung dan alu pada saat menumbuk padi, indah untuk didengarkan sebagai nada yang bernilai seni. Kegiatan ini juga memunculkan inspirasi seniman untuk menciptakan lagu " Lesung Jumengglung" yang terkenal sejak jaman dulu sampai sekarang. Nilai budaya juga tercermin dari bentuk alat pertanian tradisional. Bentuknya 
sederhana, tetapi mengandung unsur seni. Misalnya bentuk ani-ani yang mirip burung, bentuk sabit mirip bulan sabit, tampi dan keranjang yang teranyam rapi, dan sebagainya. Petani yang masih menggunakan peralatan pertanian tradisional ini secara tidak langsung ikut andil dalam melestarikan budaya yang diwariskan oleh leluhur.

\section{Nilai sosial}

Dalam pertanian tradisional yang dilakukan masyarakat pedesaan masih memegang teguh prinsip gotong royong, saling membantu secara bergiliran. Hal ini menyebabakan hubungan kekeluargaan satu orang dengan lainnya menjadi semakin erat, saling membutuhkan dan membantu untuk menghasilkan produktivitas kegiatan pertanian. Kebersamaan dapat pula dilihat pada saat pengolahan tanah, penanaman, penyiangan sampai pemanenan hasil pertanian. Misalnya pada saat panen padi, para tetangga ikut membantu tanpa diberi upah dan membawa hasil panen ke rumah pemiliknya menggunakan alat angkut keranjang ataupun gerobak. Pembagian pekerjaan disesuaikan dengan kemampuan. Untuk pekerjaan yang berat dilakukan oleh laki-laki, misalnya membajak dan mencangkul; sedangkan pekerjaan yang lebih ringan dilakukan oleh perempuan, misalnya menanam dan memanen padi.

\section{Nilai ekologi}

Alat pertanian tradisional digerakkan dengan tenaga manusia, sehingga ramah lingkungan. Berbeda dengan alat pertanian modern yang menggunakan mesin ataupun listrik untuk mengoperasikannya. Bahan bakar dari penggunaan mesin akan menyebabkan pencemaran lingkungan sekitar. Dampak dari pencemaran ini akan menyebabkan rusaknya tanah dengan terkikisnya kandungan unsur hara yang menurunkan kesuburan. Selain itu, buangan bahan bakar dari mesin peralatan pertanian modern (misalnya traktor, threser, dan lainlain) akan menyebabkan pencemaran udara yang dapat merusak sistem pernapasan makhluk hidup.

\section{PENUTUP}

Salah satu akibat yang
ditimbulkan dari modernisasi di
bidang pertanian adalah semakin
terkikisnya penggunaan peralatan
pertanian tradisional oleh petani yang
cenderung beralih pada peralatan
pertanian yang modern. Peralatan
pertanian tradisional perlu untuk
dilestarikan karena mengandung
nilai-nilai yang berakar pada budaya
bangsa. Bentuk pelestariannya yakni
dengan perlindungan, baik hukum
melalui peraturan maupun kebijakan
terkait pelestarian warisan budaya.
Dokumentasi dan pelestarian berupa
pameran alat pertanian tradisional
di museum juga di perlukan agar
warisan kekayaan ini tidak punah
dan masih dapat di perlihatkan pada
generasi mendatang. Pelestarian
warisan budaya bangsa juga dapat
dilakukan melalui pendidikan, yakni
dengan menyisipkan pengetahuan
tersebut dalam pembelajaran siswa
di sekolah. Hal ini diharapkan dapat
menumbuhkan kesadaran tentang
pentingnya melestarikan budaya
sebagai jati diri bangsa.

Salah satu akibat yang ditimbulkan dari modernisasi di bidang pertanian adalah semakin terkikisnya penggunaan peralatan pertanian tradisional oleh petani yang cenderung beralih pada peralatan pertanian yang modern. Peralatan pertanian tradisional perlu untuk dilestarikan karena mengandung nilai-nilai yang berakar pada budaya bangsa. Bentuk pelestariannya yakni dengan perlindungan, baik hukum melalui peraturan maupun kebijakan terkait pelestarian warisan budaya. Dokumentasi dan pelestarian berupa di museum juga di perlukan agar warisan kekayaan ini tidak punah dan masih dapat di perlihatkan pada generasi mendatang. Pelestarian warisan budaya bangsa juga dapat dilakukan melalui pendidikan, yakn tersebut dalam pembelajaran siswa di sekolah. Hal ini diharapkan dapa menumbuhkan kesadaran tentang sebagai jati diri bangsa. 


\section{DAFTAR PUSTAKA}

Anonim. 2011. http://www.museum.pusaka-nias.org/2011/10/peralatan-tradisional-nias-1. html (diakses tanggal 2 Oktober 2014).

Anonim. 2012. http://kelompokternakpucakmanik.blogspot.com/2012/01/mengenal-alattradisional-pertanian.html (diakses tanggal 3 Oktober 2014).

Djhonson, D.P. 1994. Teori Sosiologi Klasik dan Modern Jilid I. Terjemahan Robert MZ Lawang. Jakarta: Gramedia Pustaka Utama.

Hartati,S.T.D. 2011. "Peranan Dewi Sri dalam Tradisi Pertanian di Indonesia". Makalah Pertemuan IImiah Arkeologi tahun 2011, tanggal 1-3 November 2011 di Surabaya. Jakarta: Direktorat Jendral Sejarah dan Purbakala. 